\title{
Macroalgal biomass, growth rates, and diversity are influenced by submarine groundwater discharge and local hydrodynamics in tropical reefs
}

\author{
Florybeth Flores La Valle ${ }^{1,4, *}$, Florence I. Thomas ${ }^{2}$, Craig E. Nelson ${ }^{3}$ \\ ${ }^{1}$ Marine Biology Graduate Program, University of Hawai'i at Mānoa, 2525 Correa Rd., HIG 132, Honolulu, Hawai'i 96822, USA \\ ${ }^{2}$ Hawai'i Institute of Marine Biology, 46-007 Lilipuna Rd., Kaneohe, Hawai'i 96744, USA \\ ${ }^{3}$ Center for Microbial Oceanography: Research and Education (C-MORE), Department of Oceanography, \\ University of Hawai'i at Mānoa and University of Hawai'i Sea Grant, 1000 Pope Rd., Honolulu, Hawai'i 96822, USA \\ ${ }^{4}$ Present address: Department of Environmental Science, Policy, and Management, University of California, Berkeley, \\ Mulford Hall, 130 Hilgard Way, Berkeley, California 94720, USA
}

\begin{abstract}
It is critical to evaluate the in situ effects of multiple stressors on coastal community dynamics, especially those communities harboring high diversity such as coral reefs, in order to understand the resilience of these ecosystems, prepare coastal management for future scenarios, and aid in prioritizing restoration efforts. In this in situ study, at 2 sites with gradients of submarine groundwater discharge (SGD), a suite of physical parameters (wave exposure index, wind exposure index, and depth) and an all-encompassing SGD chemical parameter (average nitrate + nitrite daily load) were measured along spatially cohesive and temporally relevant scales and used to model macroalgal growth, biomass, and diversity in Maunalua Bay, Hawai'i. We showed that (1) speciesspecific macroalgal biomass is significantly related to SGD and one of the 2 exposure indices (i.e. wind exposure or wave exposure), (2) SGD and wave exposure play key roles in species-specific growth rates, and (3) SGD supports low diversity and increased biomass of species that can tolerate the biogeochemistry associated with SGD. Our work suggests that SGD and local hydrodynamics predict local variation in macroalgal growth, biomass, and diversity in tropical reefs.
\end{abstract}

KEY WORDS: Benthic algae $\cdot$ Nutrient loading $\cdot$ Algal growth $\cdot$ Algal biomass $\cdot$ Local diversity Exposure

\section{INTRODUCTION}

Physicochemical factors are important in shaping the benthic community composition of coastal systems. A major chemical process that alters the community structure and function of coastal systems is nutrient pollution. Nutrient pollution via surface runoff has been studied widely in all aquatic environments (NRC 2000, Smith 2003, Ocean Commission 2004, Ahmad et al. 2016) and has been linked to changes in benthic fauna (Magalhaes \& Bailey-Brock 2014), the persistence of deleterious algal blooms (Howarth et al. 2002), and increased macroalgal biomass in coastal ecosystems (Bell 1992, Khan \& Ansari 2005). Continuously elevated nutrient inputs on reef

${ }^{*}$ Corresponding author: lavallef@berkeley.edu systems along with decreased herbivory have been shown to be the main factors responsible for phase shifts from coral to macroalgal-dominated reefs (McCook 1999, Smith et al. 2001, 2010, Littler et al. 2006).

Submarine groundwater discharge (SGD), like fluvial runoff, is another potential source of nutrient pollution. Studies have shown that groundwater is a source of nutrients to streams, rivers, and coastal systems (Burnett et al. 2003, Zhang \& Mandal 2012). SGD can also be a source of land-based nutrients to coral reefs in high island systems (Paytan et al. 2006, Nelson et al. 2015). In areas where the nutrient concentration of coastal groundwater has been substantially increased by land use, nutrient loading to coastal waters via SGD has been associated with

() The authors 2019. Open Access under Creative Commons by Attribution Licence. Use, distribution and reproduction are unrestricted. Authors and original publication must be credited. 
macroalgal blooms and shifts in community composition (Naim 1993, McCook 1999, Costa et al. 2008, Lyons et al. 2014).

McClanahan et al. (2002) found that the interaction of persistent and multiple synergistic disturbances is often the cause of permanent phase shifts in coral reef communities. SGD in island settings has variable biogeochemical parameters such as salinity, $\mathrm{pH}$, dissolved organic matter (DOM), dissolved inorganic nutrients, as well as other associated chemical factors, which vary by aquifer and land use (Knee et al. 2010, Young et al. 2015, Richardson et al. 2017b). In watersheds experiencing high contamination of groundwater by land-based nutrients, SGD is a chronic source of nutrients to coastal systems due to its continuous or tidal mode of delivery (Richardson et al. 2017 b). Additionally, in systems experiencing semidiurnal tides, SGD and all its associated geochemistry fluxes can be high (Johnson et al. 2008, Holleman 2011). The multiple stressors associated with SGD leave reef systems vulnerable to permanent ecological transitions to algal-dominated states at sites with large freshwater SGD fluxes with high nutrient concentrations (Lapointe 1997, Smith et al. 2005).

The composition and abundance of the algal assemblage on a reef with SGD depend on which species can thrive in this chemical and physical environment. All marine primary producers have an optimal range of nutrient concentrations and salinity for growth and production. Both of these environmental variables control major physiological functions; salinity drives osmotic and solute regulation (Wiencke \& Bischof 2012), while nutrient concentrations drive uptake rates and productivity (Valiela et al. 1997, Thomas \& Cornelisen 2003). Shallow coastal waters with freshwater SGD undergo both nutrient load and salinity changes on small time scales (i.e. tidal, hourly) (Johnson et al. 2008). Algal communities living in nutrient and salinity variations on this time scale require the ability to acclimate quickly to wide ranges of these chemical parameters. These environmental conditions can preferentially spur the growth of some algal species over others. For example, studies have shown that the growth rate of Gracilaria sp. is optimal at salinities of 15-30 (Israel et al. 1999, Choi et al. 2006). This suggests that there are species better adapted to tolerate coastal systems with high freshwater SGD flux.

Additionally, the success of certain algal species in reef flats depends on their ability to withstand hydrodynamic forces such as exposure to wind and waves. Fringing reef flats are shallow and close to shore, making them vulnerable to sedimentation from adja- cent land and increased turbidity with wave action (Airoldi 1998, Elfrink \& Baldock 2002, Balata et al. 2007). Water motion directly dictates algal growth and composition by imposing physical stress (D'Amours \& Scheibling 2007) and varying nutrient delivery depending on the hydrodynamic forces acting on the area (Hurd 2000, Thomas \& Cornelisen 2003). For example, studies have shown that even when nutrient delivery is greatest at a reef crest, macroalgal growth is minimal due to wave action (Hurd 2000, Lilliesköld Sjöö et al. 2011). The physical structure (i.e. morphology, flexibility, size) of benthic species affects their ability to tolerate the mechanical forces of drag and lift and their physiological ability to take up nutrients by creating a thinner or thicker diffusive boundary layer (Koehl 1986, Denny et al. 1989, Carrington 1990, Koch 1993, Hurd 2000). The effects of wave and wind action vary with species morphology and structure, creating differential effects on the abundance of different species. This, in turn, explains why wave action and hydrodynamic forces play a major role in shaping the benthic community composition, diversity, and species richness of marine ecosystems (Costa et al. 2000, Nishihara \& Terada 2010).

Previous work has shown that both eutrophication and wave exposure have significant effects on algal assemblages in the coastal zone (Pihl et al. 1999, Flores et al. 2015) but no studies have looked at these factors together on algae-dominated reef flats with SGD. Maunalua Bay, located on the southeastern shore of Oahu, Hawai'i, has 3 algal-dominated fringing reefs that extend from shore to about 200-400 m offshore, with groundwater input occurring at the shoreline. The SGD at 2 of these sites, Black Point and Wailupe, is lower in salinity ( 2-4) and highly enriched in nutrients compared to surrounding coastal waters, thus providing an interesting study site for the interaction of these physical and chemical factors with the macroalgal communities. Additionally, the fringing reefs of Black Point and Wailupe (see Fig. 2) have been the site of a previous study defining biogeochemical zones associated with SGD (Nelson et al. 2015). These zones (i.e. spring, transition, diffuse, and ambient zones) are characterized by different degrees of SGD influence - with the spring zone being the site of the groundwater discharge and therefore having the highest SGD influence, to the ambient zone, which is the furthest away from the SGD and has the least amount of SGD influence. The gradient of freshwater and nutrient inputs across these zones also creates interesting study sites for in situ algal growth experiments. 
Black Point and Wailupe are dominated by invasive macroalgal species and, due to the reefs' coastal topography, these sites experience a range of both wave and wind exposure. This study explores the relationships between exposure and nutrient load on a local scale $(\sim 400 \mathrm{~m})$ with respect to algal biomass, growth, and diversity in situ. We hypothesized that (1) species-specific and macroalgal biomass depend on SGD and at least one index of exposure, (2) species-specific growth rates will vary with SGD and herbivory, and (3) that diversity is related to both nutrient load and one or more exposure indices. Overall, our goal was to evaluate the in situ effects of SGD in the context of the hydrodynamic state of these reefs to better understand their combined effects on macroalgal population and community dynamics.
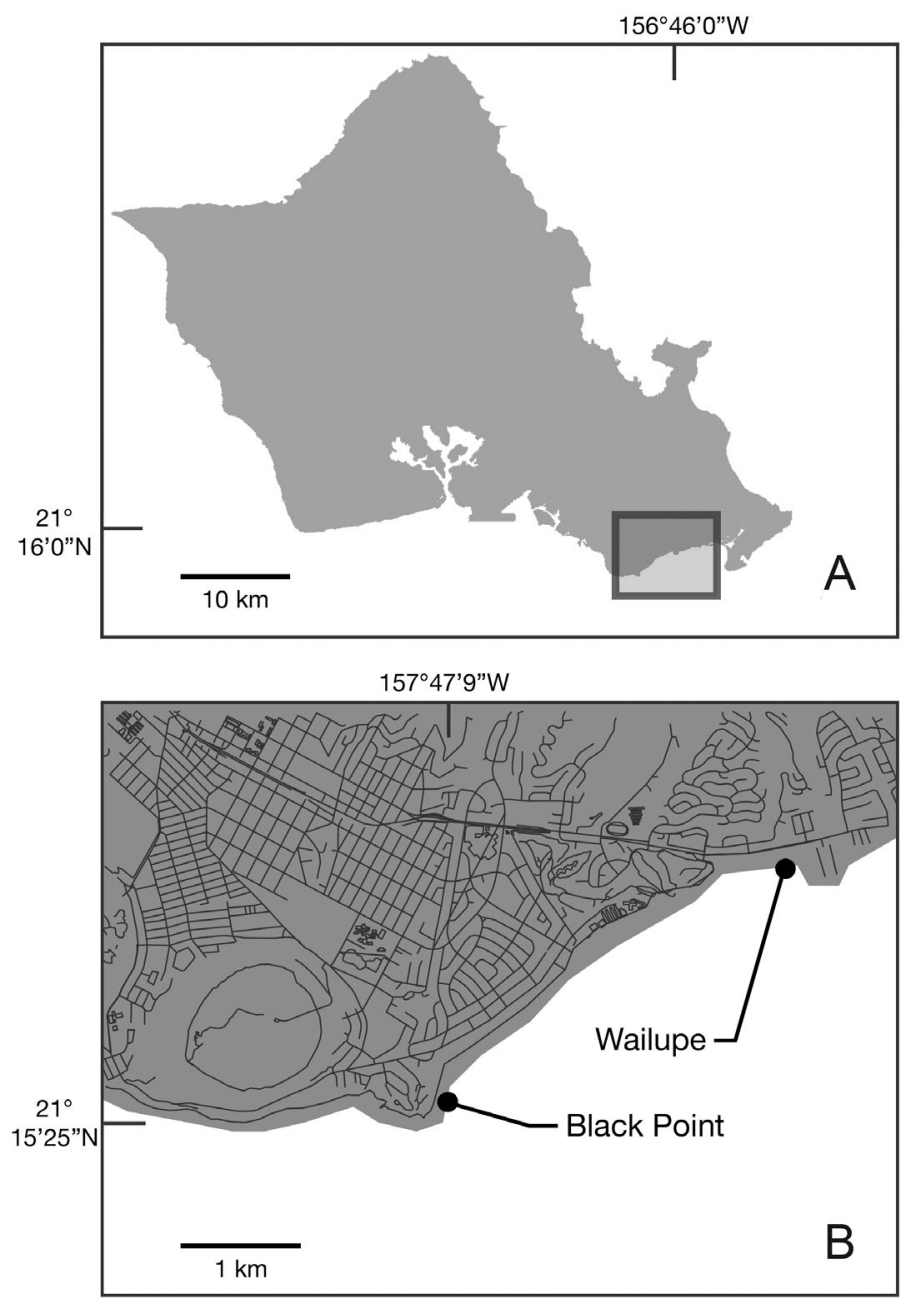

Fig. 1. Sampling locations on (A) O'ahu, Hawai'i; rectangle: the western half of Maunalua Bay. (B) Close up of the coastline of western Maunalua Bay. Markers indicate the 2 sites with submarine groundwater discharge: Black Point and Wailupe

\section{MATERIALS AND METHODS}

\subsection{Study site descriptions}

The 2 study sites are areas with known groundwater input along the southern coast of $\mathrm{O}^{\prime} \mathrm{ahu}$, Hawai'i, in Maunalua Bay $\left(21.2743^{\circ} \mathrm{N}, 157.7492^{\circ} \mathrm{W}\right.$; Fig. 1A). Salinity and ${ }^{222} \mathrm{Rn}$ surveys of the bay's coastline indicated 3 areas with groundwater signatures and negligible surface water inputs (Richardson et al. 2017a). This study focused on 2 reef flats in the bay: Black Point $\left(21.2586^{\circ} \mathrm{N}, 157.7899^{\circ} \mathrm{W}\right)$ and Wailupe $\left(21.2756^{\circ} \mathrm{N}, 157.7624^{\circ} \mathrm{W}\right)$ (Fig. 1B). These 2 sites are about $4 \mathrm{~km}$ away from each other and receive SGD sourced from 2 different watersheds with different nutrient profiles and sources, possibly due to near-shore geochemical and geological differences (Richardson et al. 2017b).

The reef flats are algae-dominated, and SGD discharge rates range from $128 \mathrm{~m}^{3} \mathrm{~d}^{-1} \mathrm{~m}^{-1}$ of coast at Black Point compared to $20 \mathrm{~m}^{3} \mathrm{~d}^{-1} \mathrm{~m}^{-1}$ of coast at Wailupe (Holleman 2011). Concentrations of inorganic nutrients at Black Point average $190 \mu \mathrm{M} \mathrm{NO}_{3}{ }^{-}$ $\mathrm{l}^{-1}$ and $3 \mu \mathrm{M} \mathrm{PO}_{4}{ }^{3-} \mathrm{l}^{-1}$ resulting in groundwaterderived nutrient fluxes of $8902 \mathrm{~mol} \mathrm{NO}_{3}^{-} \mathrm{d}^{-1} \mathrm{~km}^{-1}$ shoreline and $238 \mathrm{~mol} \mathrm{PO}_{4}{ }^{3-} \mathrm{d}^{-1} \mathrm{~km}^{-1}$ shoreline (Holleman 2011). At Wailupe spring, nutrient concentrations average $68 \mathrm{\mu M} \mathrm{NO}_{3}{ }^{-} \mathrm{I}^{-1}$ and $2 \mathrm{\mu M} \mathrm{PO}_{4}{ }^{3-}$ $\mathrm{l}^{-1}$, resulting in groundwater-derived nutrient fluxes of 1090 and $51 \mathrm{mmol} \mathrm{d}^{-1}$ of $\mathrm{NO}_{3}{ }^{-}$and $\mathrm{PO}_{4}{ }^{3-}$, respectively (Holleman 2011, Richardson et al. 2017a). Nutrient concentrations of SGD at both sites are at least 2 orders of magnitude higher than background levels.

\subsection{Calculating nutrient loads}

\subsubsection{Water sampling and processing}

We established a relationship between salinity and nutrients by compiling a time series of surface and benthic water samples taken synoptically along the SGD gradient at Wailupe and Black Point ( $\mathrm{n}=150$ site $^{-1}$ ) on 10 and 11 January 2015, respectively. Water samples were analyzed for salinity using a combination platinum ring electrode thermistor (Metrohm 6.0451.100) on a Metrohm conductivity module with Tiamo software (v.2.4). A subset of 48 samples for Black Point and 40 samples for Wailupe were analyzed for inorganic nutrients, covering the largest range of salinities to represent water samples with a range of groundwater fractions. These water samples were filtered through a $0.2 \mu \mathrm{m}$ filter (Whatman 6900- 
2502 PVDF filtration medium) and refrigerated for $3 \mathrm{wk}$. The samples were brought to room temperature, mixed, and analyzed on a Seal analytical segmented flow injection autoanalyzer AA3HR for nitrate + nitrite $(\mathrm{N}+\mathrm{N})$, silicate $\left(\mathrm{SiO}_{4}{ }^{2+}\right)$, and total dissolved phosphorus (TDP). These parameters were regressed against salinity and showed strong linear relationships (least squares regressions: $\mathrm{R}^{2}>0.964, \mathrm{p}<0.001$; see Table 1 for the linear relationships between the nutrients and salinity by site). The strong relationship between salinity and nutrients allowed us to use salinity as a proxy for the nutrients listed above.

\subsubsection{Salinity time series and nutrient load calculations}

Autonomous salinity sensors (Odyssey temperature and conductivity loggers; 3 to $60 \mathrm{mS} \mathrm{cm}^{-1}$ ) were deployed in a sparse grid $(n=23)$ across each site (Fig. 2, red triangles). The sensors were deployed at Wailupe for 34 d (17 April-21 May 2015) and at Black Point for 30 d (29 May-29 June 2015). The sampling frequency was 1 measurement every $10 \mathrm{~min}$. Water samples were taken while each sensor was deployed and were analyzed using a Portasal salinometer 8410A (accuracy 0.001) and were compared to sensor values for quality control (QC) purposes.

The salinity data were used to calculate the TDP, $\mathrm{SiO}_{4}{ }^{2+}$, and $\mathrm{N}+\mathrm{N}$ time series across space and time at each location at both sites. The time series data were then used to calculate an average daily nutrient load at each location. $\mathrm{N}+\mathrm{N}$ is used as a representative parameter for models and figures but should be treated as a representative variable for this larger suite of SGDrelated parameters. Average daily $\mathrm{N}+\mathrm{N}$ load was then interpolated across space to create a continuous map of daily nutrient loads for both sites (see Fig. 3A,B).

\subsection{Biological parameters}

\subsubsection{Determining algal biomass}

Survey areas for each site were set to encompass areas with high to low SGD impact based on the distinct biogeochemical zones described in Nelson et al. (2015). In decreasing order of SGD influence, these zones are spring (site of SGD), transition, diffuse, and ambient (Fig. 2, shaded areas). The area covered for Wailupe and Black Point respectively was about $0.11 \mathrm{~km}^{2}$ (440 $\mathrm{m}$ offshore by $250 \mathrm{~m}$ alongshore) and $0.020 \mathrm{~km}^{2}$ (155 $\mathrm{m}$ offshore by $130 \mathrm{~m}$ alongshore). The sites were divided into $3 \times 3$ grids, resulting in 9 cells with the same rectangular dimensions; 4-5 random points were chosen within each cell (i.e. stratified random sampling) for benthic algal surveys (Fig. 2, black circles). We used $0.01 \mathrm{~m}^{2}$ quadrats to measure species-specific percent algal and coral cover, as well as substrate type. All of the algae within the quadrat were collected, identified, separated by species, dried for $3 \mathrm{~d}$ at $60^{\circ} \mathrm{C}$, and weighed for dry biomass. Seasonal surveys spanned 2014-2016 but only the fall (i.e. September to November) data were used
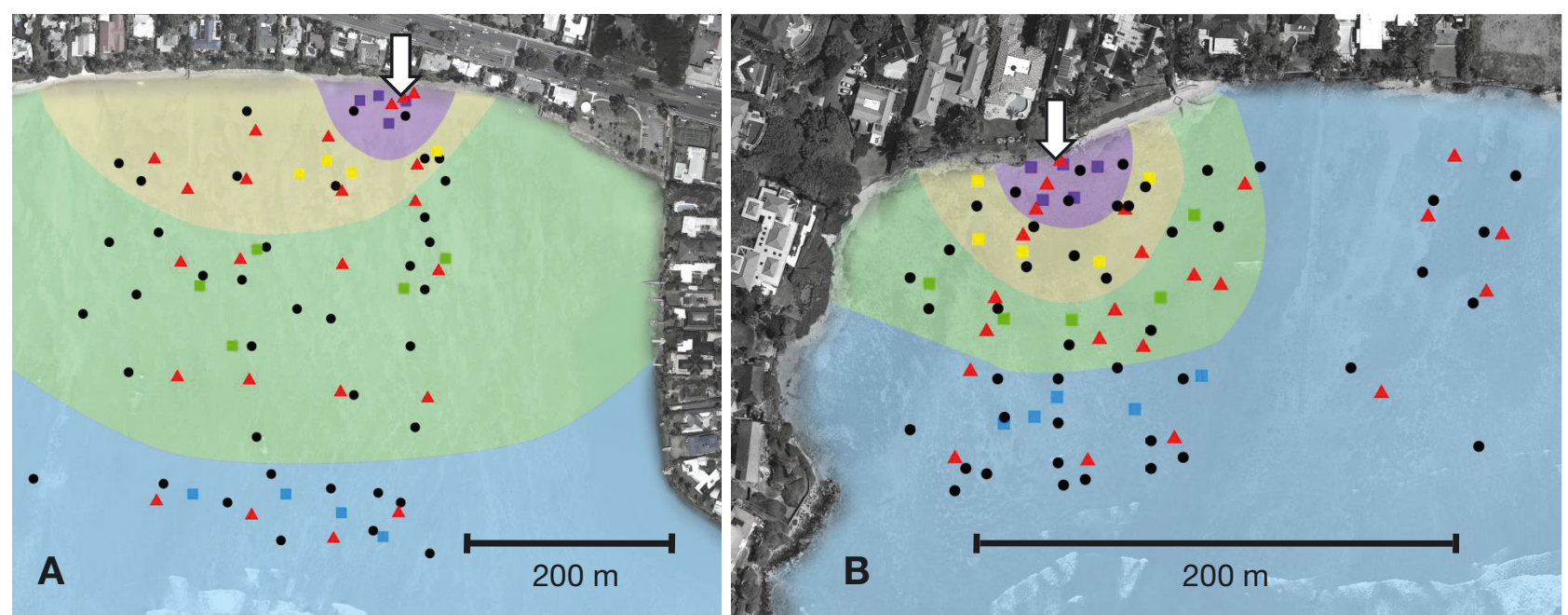

Fig. 2. Experimental design and sampling locations at (A) Wailupe and (B) Black Point. White arrow: localized submarine groundwater discharge (SGD); black circles: sites where species-specific biomass, diversity, depth, wave exposure, and wind exposure were measured; red triangles: salinity sensor locations. Reef shading represents the biogeochemical zones described in Nelson et al. (2015): purple: spring zone (site of SGD); yellow: transition zone; green: diffuse zone; blue: ambient zone. Color-coded squares represent the sites of the growth experiments, stratified by biogeochemical zone 
because this season yielded surveys with the highest algal biomass (fall 2014 and 2015).

\subsubsection{Measuring herbivory and algal growth rates in situ}

Algal relative growth rates and herbivory rates were measured in caged, open caged, and no cage growth and herbivory assays, using a method similar to Stimson et al. (1996). Unlike Stimson's methodology, our cages were made of plastic-coated galvanized wire (mesh coarseness: $1 \mathrm{~cm}^{2}$ ). A total of 16-20 experimental setups consisting of one cage, one open cage, and one no cage treatment were deployed at each site (Fig. 2, colored squares), with 4-5 replicates in each of the 4 biogeochemical zones (spring, transition, diffuse, and ambient) (Nelson et al. 2015). We placed the experiments in 4 zones of varying SGD influence in order to capture the SGD gradient. The replicates in each zone by site were deployed simultaneously for periods of $5 \mathrm{~d}$ and relative growth rates were calculated as the percent change in biomass over $5 \mathrm{~d}$. We used Gracilaria salicornia (invasive), Avrainvillea amadelpha (invasive), Acanthophora spicifera (invasive), and Halimeda discoidea (native) at Wailupe because they are the most abundant representatives of the macroalgal species at this site. Likewise, for the herbivory and growth experiments at Black Point, Bryopsis pennata (native but invasive at this location), Avrainvillea amadelpha (invasive), Acanthophora spicifera (invasive), and Halimeda discoidea (native) were used. Species- and site-specific 2-way ANOVAs were run using treatment (i.e. cage, open cage, no cage) and zone (i.e. spring, transition, diffuse, and ambient) as factors with an interaction between them, and only biogeochemical zone was reported as significant in most species (Table S1 in the Supplement at www.int-res.com/articles/suppl/m621p051_supp.pdf); therefore, herbivory was not significant in either zone, at any site, or for any species. Due to these results and because some algae was detaching from the attachment sites in the cage setups during high wave action periods, we switched methodology to one based on Fong et al. (2006), which used mesh bags $\left(5 \mathrm{~mm}^{2}\right.$ polyester mesh) to encapsulate the algae and measure relative growth rates in the absence of herbivory. This methodology allowed us to measure growth in the same manner, and it standardized the loss of algal biomass due to wave exposure. All of the sites were less than $1.5 \mathrm{~m}$ deep and previous photosynthetically active radiation (PAR) data collected at these sites found that even a $50 \%$ decrease by the mesh would allow for photosynthesis and growth. This method was laid out in the same spatial way as the original method based on biogeochemical zones and replicated 2 times at each site. Roughly $5 \mathrm{~g}$ of algae of each algal species were deployed initially. Exact wet weight was measured in the field before deployment and then measured again $5 \mathrm{~d}$ after the deployment. This is a common method used, especially in Hawaiian algal studies (Vermeij et al. 2009, Reef et al. 2012), as algae do not grow very large in oligotrophic waters. This length of time allowed for significant changes in biomass of the algae. Growth experiments were done from June to November 2015.

\subsubsection{Diversity index: Simpson's index}

Simpson's diversity index (SDI) in this case is the complement of Simpson's original index (Simpson 1949) and represents the probability that 2 randomly chosen individuals belong to different species (McCune \& Grace 2002). This index was chosen because it includes both a measure of richness and abundance and for its interpretative simplicity. SDI accounts for a small data set and assumes sampling without replacement. A further strength of this measure is its reduced dependence on sampling effort compared with species richness (Magurran 2004).

Simpson's diversity index is calculated as:

$$
D_{1}=\frac{1-\sum_{i=1}^{R} n_{i}\left(n_{i}-1\right)}{N(N-1)}
$$

where $R$ is the number of species (richness), $n_{i}$ is the percent cover of a particular species and $N$ is the total percent cover of all species. SDI was calculated for all the locations where benthic surveys were done (Fig. 2, black circles).

\subsection{Physical parameter measurements and spatial distribution maps for all parameters}

All physical parameters were calculated and measured at the benthic survey locations (Fig. 2, black circles). A wind exposure index (Keddy 1982) was calculated for all benthic survey locations at Wailupe and Black Point. Wind exposure (Exp) is given by the following equation:

$$
\operatorname{Exp}=\sum_{j=1}^{8}\left(V_{i} \times P_{i} \times F_{i}\right)
$$

where $i$ is $i^{\text {th }}$ compass heading $(1=\mathrm{N}, 2=\mathrm{NE}, 3=\mathrm{E}$, $4=\mathrm{SE}, 5=\mathrm{S}, 6=\mathrm{SW}, 7=\mathrm{W}, 8=\mathrm{NW}), V$ is the average 
monthly maximum wind speed in $\mathrm{m} \mathrm{s}^{-1}, P$ is percent frequency with which wind occurred from the $i^{\text {th }}$ direction, and $F$ is effective local fetch. Effective local fetch was measured using Google Earth Pro (v.7.1.7.2606) as the distance from the point to the closest barrier such as land or reef crest. Average monthly maximum wind speed and percent wind frequency were calculated by taking 2012 data from a buoy (Station OOUH1: $21.3033^{\circ} \mathrm{N}, 157.8644^{\circ} \mathrm{W}$; National Buoy Data Center 2017) about 9 and $11 \mathrm{~km}$ from Black Point and Wailupe, respectively.

A wave exposure index was calculated using the same formula as above, substituting monthly average wave height for monthly maximum wind speed. $V$ was substituted with $W$, the average monthly wave height (in m). Depth was measured at each benthic survey location for each site by measuring the water column height (in $\mathrm{m}$ ) at variable tidal heights and adjusting these values to a mean lower low water (MLLW) tidal height of zero.

Spatial distributions were created using the 'interp' function in R (v.1.0.44) on spatially explicit points for each variable. The 'interp' function specifies a linear interpolation within the boundaries of the data and can be found in the 'akima' package (Akima \& Gebhardt 2015) supported by R software (see Fig. 3C-H).

\subsection{Generalized additive models for biological responses predicted by physical and SGD-related chemical parameters}

Generalized additive models (GAMs) were used in the 'mgcv' package (Wood 2011) in R to explore the relationships between the biological parameters and physical variables including SGD-related nutrient load. GAMs are semi-parametric extensions of generalized linear models (GLMs) that use non-parametric, data-defined smoothers to fit non-linear response curves (Hastie \& Tibshirani 1990, Wood 2006, Zuur et al. 2007). The underlying assumption for GAMs is that the functions are additive and that the components are smooth. The strength of GAMs is their ability to deal with non-linear and non-monotonic relationships between the response and the set of explanatory variables. We did not want to assume a predetermined relationship between the predictors and the responses. Rather, we wanted the data to determine the nature of the relationship between the response variables and the explanatory variables. The data used for the GAMs included biological responses such as species-specific algal biomass (dry weight, $\mathrm{g} \mathrm{m}^{-2}$ ), total algal biomass (dry weight, $\mathrm{g} \mathrm{m}^{-2}$ ), species-specific average percent growth over $5 \mathrm{~d}$ (see Table 2), and SDI. The predictors used in the GAMs were an array of SGD-derived chemical (sitespecific average $\mathrm{N}+\mathrm{N}$ load $\mathrm{d}^{-1}$ ) and local physical parameters (i.e. wave exposure index, wind exposure index, and depth). The predictors were checked for collinearity and were not significantly correlated (Table S2). These models allowed us to assess how much variation in the response variable each covariate can explain individually, while accounting for spatial autocorrelation. Species-specific biomass, wind exposure, wave exposure, and depth were all measured at the same locations (Fig. 2, black circles). The values for $\mathrm{N}+\mathrm{N}$ (a proxy for SGD) for the GAMs were calculated from the salinity time series (Fig. 2, red triangles) interpolated to the benthic survey locations (Fig. 2, black circles). Mean relative growth rates by biogeochemical zones were applied to the benthic survey locations (Fig. 2, shaded areas). This resulted in all response and predictor variables being on the same spatial grid $(n=82)$. All of these data sets were measured within the same grids across the reef flats and therefore are spatially cohesive over longer time scales (i.e. seasonally and yearly), which is the temporal scale at which we measured the variables used in these models. We measured parameters (SGD [as $\mathrm{N}+\mathrm{N}$ ], wave exposure, wind exposure) in a way that would account for their largest cyclical variation. For example, wave and wind exposure vary with season and therefore were summarized by year. SGD varies with tide and therefore we measure this through a $30 \mathrm{~d}$ period encompassing a spring and neap tide. Our surveys were done in the fall months over $2 \mathrm{yr}$ to capture a time period with most algal biomass. Thus, the data sets used for the GAMs were both spatially cohesive and temporally comprehensive.

It is possible that there could be interactions between wave exposure and SGD, but the parameter we chose to represent SGD was an integrated $\mathrm{N}+\mathrm{N}$ daily loading from SGD using a $30 \mathrm{~d}$ high frequency time series. This time series would have implicitly captured any interaction between SGD and exposure. Hence, we did not include an interaction, as the SGD parameter inherently includes this interaction.

\section{RESULTS}

\subsection{Spatial distributions of biological, chemical, and physical data}

Fig. 3A,B shows the distribution of average daily $\mathrm{N}$ $+\mathrm{N}$ load over Black Point and Wailupe, respectively. 

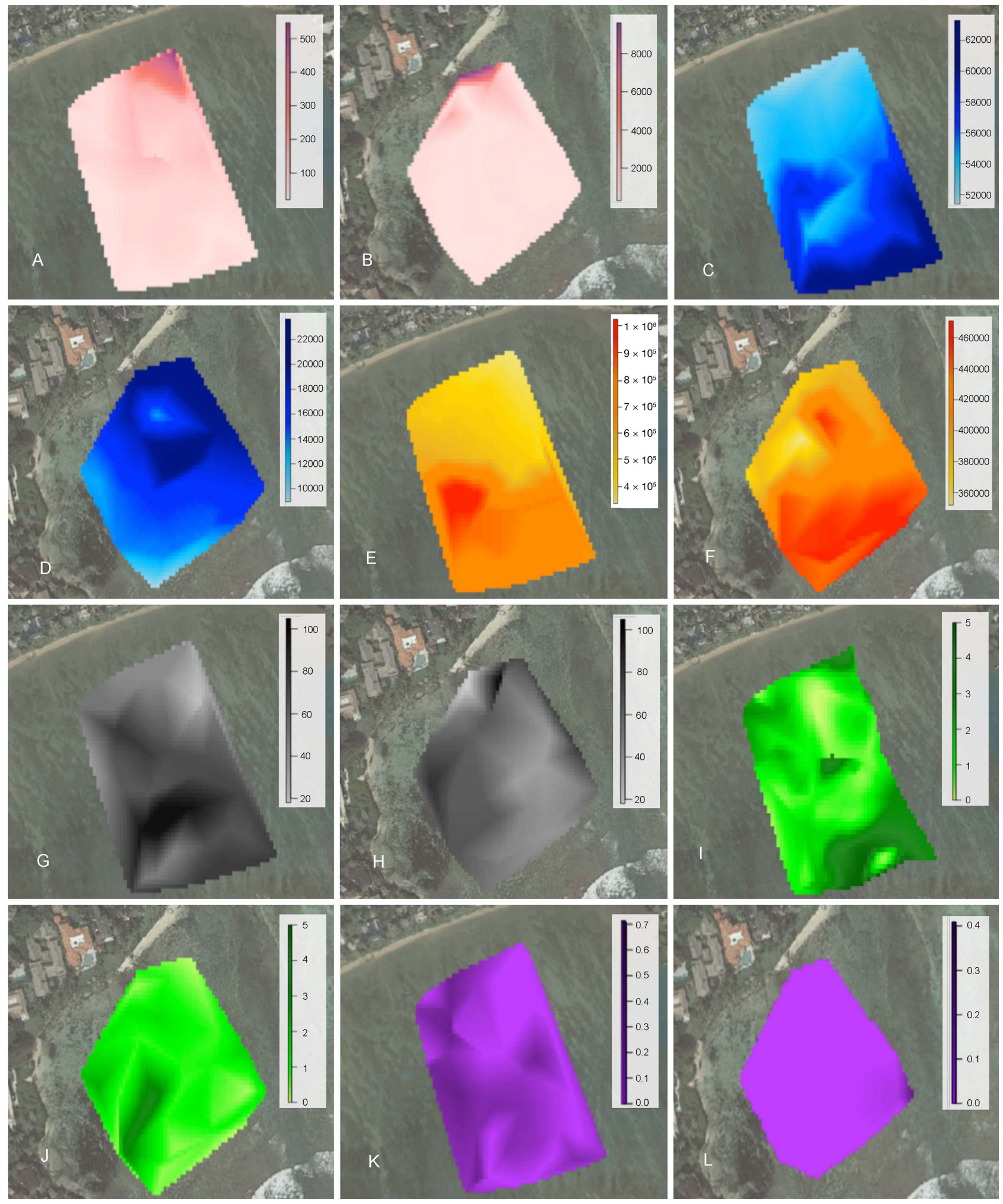

Fig. 3. Biological and physicochemical parameters used in the generalized additive models (GAMs): average daily nitrate and nitrite nutrient load (units are $\mu \mathrm{mol} \mathrm{l}^{-1}$ seawater) for (A) Wailupe and (B) Black Point; average monthly wave exposure index (unitless) for (C) Wailupe and (D) Black Point; average monthly wind exposure index (unitless) for (E) Wailupe and (F) Black Point; water column depth $(\mathrm{cm})$ normalized to zero mean lower low water at $(\mathrm{G})$ Wailupe and $(\mathrm{H})$ Black Point; total dry weight $\left(\mathrm{g} \mathrm{m}^{-2}\right)$ for (I) Wailupe and (J) Black Point; and Simpson's diversity index (unitless) for (K) Wailupe and (L) Black Point 
Table 1. Linear relationships between nutrients and salinity at Black Point and Wailupe sites. These relationships were determined using linear regressions obtained from salinity vs. nutrient plots. $\mathrm{N}+\mathrm{N}: \mathrm{NO}_{3}{ }^{-}+\mathrm{NO}_{2}{ }^{-}$, TDP: total dissolved phosphorus

\begin{tabular}{|lccc|}
\hline $\begin{array}{l}\text { Nutrient } \\
\text { concentrations } \\
\left(\mu \mathrm{mol}{ }^{-1}\right)\end{array}$ & $\begin{array}{c}\text { Linear } \\
\text { relationship } \\
\text { with salinity }\end{array}$ & $\mathrm{R}^{2}$ & $\mathrm{p}$-value \\
\hline Black Point & & & \\
$\mathrm{N}+\mathrm{N}$ & $-5.7 \times$ salinity +193.2 & 0.995 & $<0.001$ \\
$\mathrm{TDP}$ & $-0.1 \times$ salinity +4.1 & 0.994 & $<0.001$ \\
$\mathrm{SiO}_{4}{ }^{2-}$ & $-26.7 \times$ salinity +910.7 & 0.995 & $<0.001$ \\
$\mathbf{W a i l u p e}_{\mathrm{N}+\mathrm{N}}$ & $-2.1 \times$ salinity +70.5 & 0.990 & $<0.001$ \\
$\mathrm{TDP}^{2-}$ & $-0.1 \times$ salinity +2.1 & 0.964 & $<0.001$ \\
$\mathrm{SiO}_{4}{ }^{2-}$ & $-23.7 \times$ salinity +817.6 & 0.998 & $<0.001$ \\
\hline
\end{tabular}

The nutrient loads differed by site by nearly one order of magnitude (Table 1), which is consistent with past studies (Richardson et al. 2017b). Nutrient load decreased with distance from the seep due to mixing and uptake. As mentioned in Section 2.2, N + $\mathrm{N}$ was used for display purposes as the representative of a larger suite of nutrients, which all showed strong linear trends with salinity $(\mathrm{N}+\mathrm{N}$, TDP, and $\mathrm{SiO}_{4}{ }^{2-}$; refer to Table 1) and which we refer to as SGD from now on; average daily $\mathrm{N}+\mathrm{N}$ load was chosen as a proxy for groundwater influence in the GAMs because it is representative of the time scale relevant to the biological processes we tested as response variables (i.e. growth, biomass, diversity).

Average monthly wave exposure (Fig. 3C,D) was much higher at Wailupe due to its longer reef flat. This affects the fetch measurement and overall calculation for the wave exposure index (Eq. 2). The distribution of wave exposure was higher close to shore and close to the seep at Black Point and was lower away from the seep. The opposite pattern was found at Wailupe. This range difference by site also applies for wind exposure, which also uses fetch in its equation. Average monthly wind exposure spaned 1 order of magnitude difference at the 2 sites (Table 2). Average monthly wind exposure (Fig. 3E,F) was generally higher away from the seep and in a patch close to the seep at Black Point. At Wailupe, wind exposure was higher offshore with a peak at a patch on the western mid-reef flat area. Average monthly wave and wind did not show significant correlations at either site and were therefore both used as covariates in the GAMs.

Depth (Fig. 3G,H) was variable across the reef flat and ranged from about $20-105 \mathrm{~cm}$. The major macroalgal species (see Table 2 for list of species) used in the growth experiments and chosen for speciesspecific biomass analyses in the GAMs are all found both intertidally and subtidally across Hawai'i (Huisman et al. 2007) and are well adapted to live within this range of depths. Additionally, PAR sensor measurements at different depths in these areas showed that no part of the reef flat was light-limited during daylight hours.

The total biomass (dry weight) maps (Fig. 3I,J) of total algae showed that both reef flats have patches with high algal biomass ( 100\% cover). The bulk of the biomass at Wailupe was made of Gracilaria salicornia, which occurs ubiquitously across the reef flat, while at Black Point the dominant macroalga was Bryopsis pennata, which displays a more patchy distribution.

Black Point is homogeneously low in macroalgal diversity (Fig. 3K,L), with 2 small patches with relatively higher diversity: one close to the seep and one offshore. Diversity measures of zero correspond to areas where there is one dominant macroalgae, and

Table 2. Growth percentages over $5 \mathrm{~d}$ for different species at different sites and zones. Zones are listed in order from closest to, and with most, submarine groundwater discharge (SGD) fraction to farthest from, and with least, SGD impact: spring, transition, diffuse, and ambient. Results are means $\pm \mathrm{SD}$; sample size in parentheses. ND: no data

\begin{tabular}{|llcccc|}
\hline \multirow{2}{*}{ Species } & \multirow{2}{*}{ Site } & \multicolumn{4}{c|}{ Mean \% growth } \\
\cline { 3 - 6 } & & Spring zone & Transition zone & Diffuse zone & Ambient zone \\
\hline Acanthophora spicifera & Black Point & $10.3 \pm 19.2(4)$ & $-8.4 \pm 14.6(4)$ & $-0.1 \pm 10.3(4)$ & ND \\
& Wailupe & $-9.6 \pm 22.1(8)$ & $-12.1 \pm 25.2(8)$ & $6.9 \pm 17.3(8)$ & ND \\
Avrainvillea amadelpha & Black Point & $-6.3 \pm 13.6(4)$ & $2.1 \pm 7.7(4)$ & $9.0 \pm 4.6(4)$ & ND \\
& Wailupe & $7.8 \pm 7.7(5)$ & $6.5 \pm 7.3(5)$ & $8.6 \pm 8.7(5)$ & $-0.3 \pm 1.9(5)$ \\
Bryopsis pennata & Black Point & $-2.2 \pm 34.4(6)$ & $-12.3 \pm 39.6(5)$ & $-8.2 \pm 37.9(5)$ & $47.2 \pm 109.6(5)$ \\
Gracilaria salicornia & Wailupe & $7.5 \pm 7.2(5)$ & $10.1 \pm 20.1(5)$ & $14.1 \pm 14.0(5)$ & $3.2 \pm 8.8(5)$ \\
Halimeda discoidea & Black Point & $-25.4 \pm 14.1(4)$ & $2.2 \pm 6.8(4)$ & $17.5 \pm 13.3(4)$ & ND \\
& Wailupe & $-2.6 \pm 13.2(4)$ & $-0.3 \pm 17.4(4)$ & $12.5 \pm 12.7(4)$ & $7.9 \pm 2.3(4)$ \\
\hline
\end{tabular}


thus the probability of picking 2 different algal species close to each other is equal to zero. Values closer to 1 represent areas with a high probability of picking different species of algae. The low diversity at Black Point was due to $B$. pennata, which also comprised the majority of the biomass. Areas with 'higher' diversity at Black Point were areas with 2 species. Wailupe generally showed higher diversity with areas containing up to 5 species quadrat ${ }^{-1}$. Wailupe showed an area with low diversity close to the SGD seep, which was dominated by G. salicornia.

\subsection{Patterns for growth: GAMs and growth experiments}

Herbivory did not play a role in macroalgal growth and abundance for the major macroalgal species present at each site. SGD, depth, and wave exposure were important predictors for the GAMs with speciesspecific growth as a response (Fig. 4). SGD showed mostly negative relationships with growth for all species except B. pennata at Black Point and G. salicornia at Wailupe. These 2 species also made up the majority of the biomass at these 2 sites (Fig. 3K,L). The growth of $B$. pennata was only positive in the ambient zone, farthest away from the seep (Table 2). Despite the negative relative growth rates in the other biogeochemical zones, during its blooming season, $B$. pennata was found to be the main algae growing abundantly close to the seep and close to shore at Black Point. The results from the growth experiments (Table 2) that showed negative growth in the first 3 zones closest to the seep were most likely due to loss of biomass due to wave action, also suggested by the high standard deviation in each zone. Interestingly, G. salicornia showed positive growth in all the biogeochemical zones (Table 2). The zones ranked ambient, spring, transition, diffuse, from smallest to largest average relative growth rates.

The following pairs of species with significant GAMs had the same directional relationships with all the predictors at the same site: Halimeda discoidea at Wailupe and Avrainvillea amadelpha at Wailupe, as well as H. discoidea at Black Point and Acanthophora spicifera at Black Point. This suggests that there are strong site effects, which may be a product of the unique physicochemical environments of each site. On the other hand, the growth of $A$. spicifera showed the same directional relationships for all the predictors at both sites: a negative relationship with SGD and positive relationships with wind exposure and depth.
Wave exposure had mostly negative or non-significant relationships with growth of all the species. Depth mostly had positive relationships with growth for all species except $H$. discoidea at Wailupe, $A$. amadelpha at Wailupe, and B. pennata at Black Point (Fig. 4). The inconsistency of the directional relationships of the physical parameters suggests that they are a synthesis of several physical processes that may act on different scales and may affect algal growth across the reef flat in different ways. For example, depth may be a proxy for turbidity at Wailupe since areas close to the seep are both deep and turbid at high tide due to the disturbance of the silty sediment. At Black Point, the relationship between depth and turbidity may be different as some deeper areas are covered in sand, while shallower areas are composed of calcified reef, both dead and alive.

\subsection{Patterns for biomass: GAMs}

Wave exposure, SGD, and wind exposure were the important predictors for the species-specific biomass models (Fig. 5). Wave exposure generally had positive relationships with species-specific biomass at Wailupe and generally negative relationships with species-specific biomass at Black Point. Interestingly, A. spicifera's biomass had the opposite relationships with wave exposure at both sites. Two species at Wailupe, G. salicornia and $H$. discoidea, showed significant and positive relationships with wave exposure. SGD mostly had a significant positive relationship with biomass for G. salicornia at Wailupe and a significant negative relationship with $A$. spicifera biomass at Wailupe. All other relationships with SGD were not significant. The significant relationships between wind exposure and biomass were negative. Depth mostly had negative relationships with biomass for all species except $B$. pennata at Black Point, total biomass at Black Point, and A. spicifera at Wailupe. The biomass of $B$. pennata was significantly predicted by wind and wave exposure, 2 physical parameters, suggesting hydrodynamics are important for the colonization and presence of this algal species.

The following pairs had the same directional relationships with all the predictors: $B$. pennata at Black Point and total biomass at Black Point; G. salicornia at Wailupe and total biomass at Wailupe. These results were supported by the benthic surveys, which showed that $B$. pennata and $G$. salicornia are the most abundant algae at Black Point and Wailupe respectively (Fig. 3I-L), and therefore are strongly 


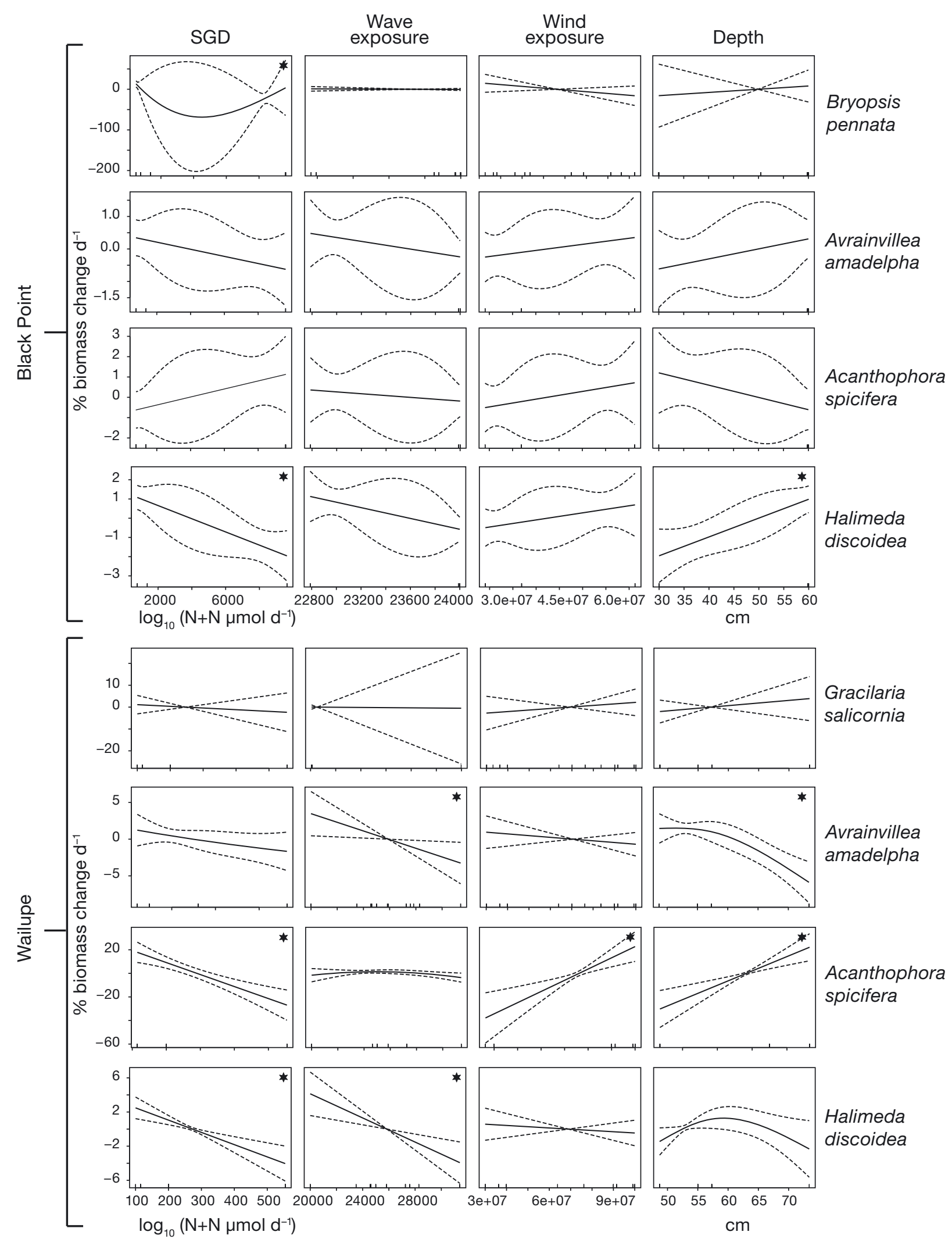

Fig. 4. Rug plots of generalized additive models with growth by species at each site as a response variable (vertical axis). Asterisk $\left({ }^{*}\right)$ indicates a significant relationship $(\mathrm{p}<0.05)$. Predictors are labeled on top of the figure (SGD: submarine groundwater discharge); wave exposure and wind exposure are unitless indices. Locations of covariate data are plotted as hash marks inside the $x$-axes. Thicker hash marks correspond to multiple data points with corresponding $x$-coordinate 


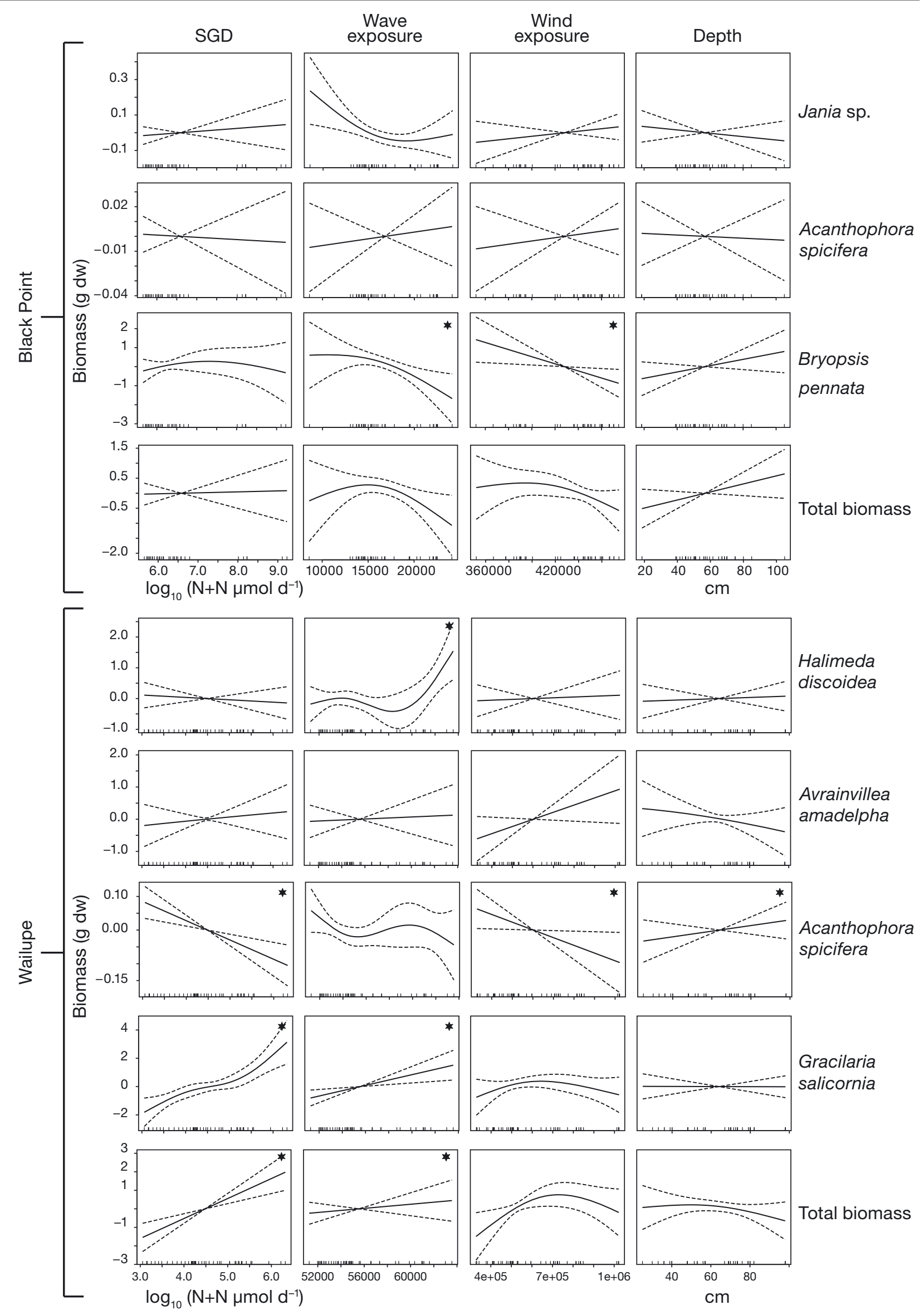

Fig. 5. Rug plots of generalized additive models with biomass by species at each site as a response (vertical axis). Asterisk $\left({ }^{*}\right)$ indicates a significant relationship $(p<0.05)$. Predictors are labeled on top of the figure. See Fig. 4 for further details 


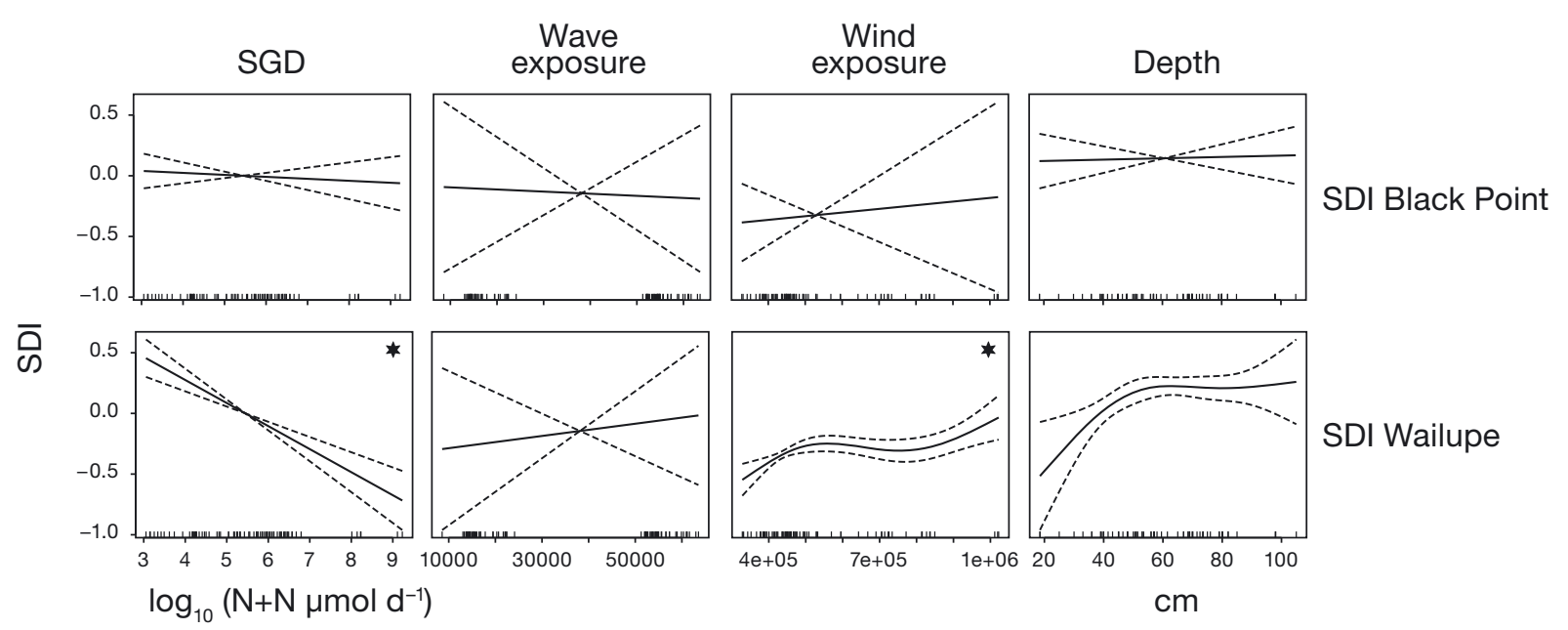

Fig. 6. Rug plots of generalized additive models with Simpson's diversity index (SDI) at each site as a response (vertical axis). Asterisk $\left({ }^{*}\right)$ indicates a significant relationship $(\mathrm{p}<0.05)$. Predictors are labeled on top of the figure. See Fig. 4 for further details

related to the total biomass response. The biomass of A. amadelpha at Wailupe, A. spicifera at Wailupe, and Jania sp. at Black Point did not show significant relationships with any of the physicochemical parameters in the GAMs.

\subsection{Patterns for SDI: GAMs}

SDI was significant at Wailupe, mostly with average daily $\mathrm{N}+\mathrm{N}$ load and wind exposure (Fig. 6). SDI was above 0 in areas with $\mathrm{N}+\mathrm{N}$ loads lower

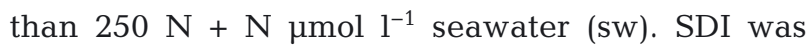
increased at higher wind exposure and depths, which both occur away from the groundwater seep. The low SDI scores close to the seep show that few species occur in areas with a distinctly different chemical environment brought in by the groundwater. Interestingly, even though diversity of algal assemblage decreased with higher nutrient loads, the total biomass of algae increased with higher nutrient loads (Figs. $5 \& 6$ ).

\section{DISCUSSION}

We calculated and measured a suite of physical, chemical, and biological characteristics on 2 reef flats with SGD input. We ran GAMs for species-specific biomass, total algal biomass, species-specific growth, and SDI against a suite of physicochemical parameters (i.e. $\mathrm{N}+\mathrm{N}$ load, wave exposure, wind exposure, depth). All biological responses for at least half of the species studied were significant with some combination of the physicochemical parameters.

\subsection{Factors predicting biomass distributions of macroalgal species}

Our first hypothesis was that species-specific macroalgal biomass depends on SGD and at least one index of exposure. This was true for (1) the biomass Gracilaria salicornia at Wailupe, which showed positive significant relationships with both SGD and wave exposure, as well as for (2) the biomass of Acanthophora spicifera at Wailupe, which had negative relationships with both SGD and wind exposure.

The rest of the significant species-specific biomass relationships occurred solely with exposure indices. The biomass of Halimeda discoidea at Wailupe had a positive significant relationship with wind exposure. The biomass of Bryopsis pennata had negative significant relationships with both wind and wave exposure. Wave exposure integrates a wide variety of environmental variables, and our results are not surprising given that the concept that hydrodynamic conditions influence the distribution of coastal organisms is not new (e.g. Fowler-Walker et al. 2006, Jonsson et al. 2006, Cefalì et al. 2016).

\subsection{SGD supports low diversity and increased biomass of species that can tolerate low salinities}

SGD was positively related to the invasive species G. salicornia and the bloom-forming species B. pennata, indicating that if found or transported to this kind of environment, these species are likely to be successful invaders. SGD had negative effects on growth with all species except B. pennata and G. sal- 
icornia, which also explains the low algal diversity in areas close to the SGD seep.

G. salicornia is found throughout the entire reef flat but was the main species found close to the SGD seep at this site. Its biomass at Wailupe was significantly positive with wave exposure and its growth was positive in all biogeochemical zones. Its growth was not highest at the spring or transition zone, which suggests that it may not thrive in this environment but it is the most tolerant of it. Smith et al. (2004) showed that Gracilaria sp. is highly tolerant of varying temperatures and desiccation. Unpublished work in aquaculture with this genus has also shown that intermediate salinities show increased growth of Gracilaria sp. (W. Ito pers. comm.). From its high biomass across the reef flat, we can infer that G. salicornia is a good biological competitor for space. G. salicornia's large range of tolerance for several chemical and physical parameters, as well as its fast-growing mechanism make it a successful invasive species. A study by Lapointe (1985) showed that a species in the Gracilaria genus was able to increase growth after frequent $\left(2 \mathrm{wk}^{-1}\right)$ nutrient pulses. He noted that frequency was more important than nutrient load for growth of this species. This study suggests that $G$. salicornia grows well in coastal systems with high nutrient loads at much higher pulse rates.

$B$. pennata was the major macroalgal species found at Black Point; however, neither its presence nor biomass were related to any of the chemical or physical parameters. This suggests that there may be other physicochemical or biological factors, such as competition, contributing to the presence and abundance of $B$. pennata across the reef flat. This alga is highly abundant across most of the reef flat but is the dominant alga in the area close to the SGD seep, possibly due to lack of competition from other algae. Offshore, although the growth data indicates that the nutrient regime/load is more ideal for its growth, there is increased competition with other algae, which also show positive growth in these biogeochemical areas.

SGD supports increased biomass of species that can tolerate low salinities. If these species are bloomforming or have high growth rates, they can take over reef flats at local spatial scales. This might be able to precipitate a succession of invasive or native algal domination on a reef. It is not surprising that macroalgal biomass is high at these sites when we combine these results with the lack of herbivory. Wailupe has been macroalgal-dominated for at least the last 15 yr (McGowan 2004); it would be interesting to pursue work on succession of algae in this system, especially with regards to invasive species.

\subsection{Diversity and macroalgal community biomass distributions}

We hypothesized that diversity is related to both nutrient load and one or more exposure indices. This was supported at Wailupe, where SID was significantly negatively related to SGD and significantly positively related to wind exposure.

The effects of exposure on the diversity of macrophytes are often unclear (Kraufvelin et al. 2010, Williams et al. 2013, Norderhaug et al. 2014). Indeed, ecological studies have shown both increasing and decreasing relationships with wave exposure, as well as hump-shaped patterns in the diversity of macroalgae (Ricketts et al. 1985, Bailey 1988, Riis \& Hawes 2003, Nishihara \& Terada 2010, Norderhaug et al. 2014).

At Wailupe, where total macroalgal biomass and diversity were significantly predicted by both exposure and SGD factors, high wind exposure occurs in areas generally away from the groundwater seep. Total biomass was positively related to wave exposure (significant) and SGD (not significant); in contrast, diversity increased with higher wind exposure and decreased with increased SGD. This supports the argument that some macroalgal species - invasive and opportunistic species in this case-can grow and persist in an area with high SGD-derived chemical factors (i.e. high nutrient and low salinity daily loads) but that most algae are outcompeted in these environments.

\subsection{SGD and physical parameters affect growth of algae species in different ways}

Finally, we hypothesized that species-specific growth rates differ by biogeochemical zone and have a significant relationship with SGD. Our growth experiment results support that species-specific relative growth rates do differ by biogeochemical zone (Table 2). For the growth of A. spicifera at Wailupe and $H$. discoidea at both sites, there was a significant negative relationship with SGD (Fig. 4). Relative growth rates of $G$. salicornia were the only ones that were positive in all zones. The relative growth rates of the same species also differed by site and biogeochemical zone; this difference could be due to the difference in magnitude of the nutrient concentrations of the SGD at the 2 sites (Table 1). We did not predict that physical parameters would have significant effects on growth, but wave exposure had significant negative relation- 
ships with growth of $A$. amadelpha and $H$. discoidea at Wailupe and a positive relationship with growth of $A$. spicifera at Wailupe.

\subsection{Distributions and growth rates of macroalgal species found away from the SGD seeps}

A. spicifera is another invasive species in Hawai'i that is common at Wailupe and present at Black Point. It is known to be able to take up nitrate (Leon-Soon 2017), which may explain its prevalence in an area where the main $\mathrm{N}$ source is groundwater-derived nitrate. A. spicifera's biomass decreased with increasing SGD and wind exposure. A study following this species' distribution showed that fragments were broken off by turbulence in the fore reef, transported by currents, and snagged or entangled in the back reef (Kilar \& McLachlan 1986). A. spicifera is also commonly known as 'prickly seaweed' in Hawai'i due to the pointy projections from the main axis which allow it to get easily entangled in things it comes into contact with. This strategy has allowed it to become one of the most prevalent invasive species in Hawai'i.

$H$. discoidea grew most and was found in areas away from the groundwater seep with high wave action at Wailupe. This result is in agreement with work by Walters \& Smith (1994) and Walters et al. (2002), which suggested that this species could be successful in areas with high wave action and grazing pressure because it is able to clonally propagate via vegetative fragmentation of very small fragments previously cut several times and in several directions. We hypothesize that $H$. discoidea is not found close to the groundwater seep because it is a calcifying alga and requires certain chemical and physical conditions such as $\mathrm{pH}$ of about 8.1 (on total scale at $25^{\circ} \mathrm{C}$ ) and carbonate/bicarbonate availability in order to calcify and grow. The groundwater that discharges at this site has lower $\mathrm{pH}$ of about 7.70 (on total scale at $25^{\circ} \mathrm{C}$ ), which does not allow for the dissociation of high concentrations of bicarbonate and carbonate ions. Thus, it is probable that areas most affected by the groundwater do not have ideal carbonate chemistry conditions for calcifying algae.

\subsection{Caveats and future directions}

The limitations of this study include a relatively low sample size for the number of parameters we were fitting in the multivariate models. This is in part the reason we ran univariate models in addition to multivariate models. The analysis presented here examines the environmental conditions and the correlations with these biological parameters and takes into account the spatial context in which they occur. By identifying the key factors associated with increases and declines, as well as presence and absence of algal taxa, the analysis highlights variables that are most clearly related to growth rates, biomass, and diversity as well as the modalities by which they interplay. This opens the way for subsequent analyses of the quantitative linkages among, for example, nutrient toxicity levels and biomass accrual. A seasonal analysis would strengthen and elucidate seasonal trends for this work, as we know that both wind and wave exposure are themselves seasonal and have seasonal effects on macrophytes (Wernberg \& Vanderklift 2010). Knowledge about the interactive effects of groundwater-derived biogeochemistry and hydrodynamic forces on macroalgal communities in shallow coastal systems is scant. Therefore, while our experimental results are sound, we acknowledge that several aspects of our interpretation require further support.

It is critical to evaluate the effects of stressors on community dynamics not only independently, but also under different combinations to understand how those effects will be played out in more realistic scenarios (Muthukrishnan \& Fong 2014). Salinity and nutrient effects on specific algae have been studied, but this is rarely done in conjunction with an exposure index. Intertidal ecologists recognize the importance of all these factors (Kraufvelin 2007, Kraufvelin et al. 2010) and in Hawai'i and other tropical areas housing coral reefs, we should apply these cross-cutting concepts and in situ studies on reef systems affected by groundwater. A good start would be to review what we know about invasive algal species in areas with coral reefs and the effects (both interactive and not) of salinity, eutrophication, and hydrodynamics.

Both from observational studies and physiological experiments, we know that macroalgal relationships between tolerance and resistance to stress are variable and species-specific (Hay et al. 2011). This is where the multiple stressor literature is helpful in trying to distill these complex interactions. Coastal systems are especially complex with upwards of 100 two-way interactions (Côté et al. 2016). In Côté et al.'s (2016) paper about ecosystem stressor interactions, they lay out a guide for identifying generalities about ecosystems, stressors, and/or responses that could provide guidance to conservation scien- 
tists and managers. Along with physiological studies about stress mechanisms, studies such as this one can accumulate data to ground truth these relationships and interactions in situ.

The information we can gather about specific algal species regarding their biomass and growth in different chemical and hydrodynamic scenarios can help us infer their fate when placed in areas with SGD and can then be expanded to estuaries and many coastal environments experiencing global changes. These systems are also important study sites for tolerance levels and thresholds for growth in different chemical loads with different temporal delivery scenarios. In the case of groundwater, these aspects are hard to disentangle, but mesocosm studies constraining factors have been done and can help elucidate these dynamics and interactions. If we can understand what factors affect biomass and persistence of certain algal assemblages, especially those comprised of invasive and opportunistic algae, we can prioritize restoration efforts. Additionally, understanding how communities of primary producers function and how resilient they may be to predicted climate change scenarios (i.e. sea level rise, increasing temperatures, etc.) will help with preparedness for coastal management.

Acknowledgements. We thank our collaborators M. Donahue, K. Lubarsky, H. Dulaiova, C. Richardson, and S. Goldberg, for their advice and support throughout the study. Field and lab help was provided by several volunteers; in particular, we thank J. Boord, S. Tomisato, and M. Thiessen. This research was sponsored by the US National Science Foundation (award OCE-1538393 to C.E.N.) and by a grant/ cooperative agreement from the National Oceanic and Atmospheric Administration, Project R/SB-10, which is sponsored by the University of Hawaii Sea Grant College Program, SOEST, under Institutional Grant No. NA14OAR 4170071 from NOAA Office of Sea Grant, Department of Commerce. The views expressed herein are those of the author(s) and do not necessarily reflect the views of NOAA or any of its subagencies. This is publication number 10708 of the School of Ocean and Earth Science and Technology of the University of Hawai'i at Mānoa and publication UNIHISEAGRANT-JC-15-26 of the University of Hawai'i Sea Grant College Program.

\section{LITERATURE CITED}

Ahmad ZU, Sakib S, Gang DD (2016) Nonpoint source pollution. Water Environ Res 88:1594-1619

Airoldi L (1998) Roles of disturbance, sediment stress, and substratum retention on spatial dominance in algal turf. Ecology 79:2759-2770

Akima H, Gebhardt A (2015) akima: interpolation of irregularly and regularly spaced data. $\mathrm{R}$ package version 0.5-12. https://CRAN.R-project.org/package=akima
Bailey RC (1988) Correlations between species richness and exposure: freshwater mollusks and macrophytes. Hydrobiologia 162:183-191

* Balata D, Piazzi L, Cinelli F (2007) Increase of sedimentation in a subtidal system: effects on the structure and diversity of macroalgal assemblages. J Exp Mar Biol Ecol 351: 73-82

Bell PRF (1992) Eutrophication and coral reefs: some examples in the Great Barrier Reef lagoon. Water Res 26: 553-568

Burnett WC, Bokuniewicz H, Huettel M, Moore WS, Taniguchi M (2003) Groundwater and pore water inputs to the coastal zone. Biogeochemistry 66:3-33

Carrington E (1990) Drag and dislodgment of an intertidal macroalga: consequences of morphological variation in Mastocarpus papillatus. J Exp Mar Biol Ecol 139:185-200

* Cefalì ME, Cebrian E, Chappuis E, Pinedo S, Terradas M, Mariani S, Ballesteros E (2016) Life on the boundary: environmental factors as drivers of habitat distribution in the littoral zone. Estuar Coast Shelf Sci 172:81-92

Choi HG, Kim YS, Kim JH, Lee SJ, Park EJ, Ryu J, Nam KW (2006) Effects of temperature and salinity on the growth of Gracilaria verrucosa and G. chorda, with the potential for mariculture in Korea. J Appl Phycol 18:269-277

Costa OS Jr, Leão ZMAN, Nimmo M, Attrill MJ (2000) Nutrification impacts on coral reefs from northern Bahia, Brazil. Hydrobiologia 440:307-315

Costa OS Jr, Nimmo M, Attrill MJ (2008) Coastal nutrification in Brazil: a review of the role of nutrient excess on coral reef demise. J S Am Earth Sci 25:257-270

Côté IM, Darling ES, Brown CJ (2016) Interactions among ecosystem stressors and their importance in conservation. Proc R Soc B 283:20152592

*D'Amours O, Scheibling RE (2007) Effects of wave exposure on morphology, attachment strength and survival of the invasive green alga Codium fragile ssp. tomentosoides. J Exp Mar Biol Ecol 351:129-142

*Denny M, Brown V, Carrington E, Kraemer G, Miller A (1989) Fracture mechanics and the survival of waveswept macroalgae. J Exp Mar Biol Ecol 127:211-228

* Elfrink B, Baldock T (2002) Hydrodynamics and sediment transport in the swash zone: a review and perspectives. Coast Eng 45:149-167

Flores AAV, Christofoletti RA, Peres ALF, Ciotti AM, Navarrete SA (2015) Interactive effects of grazing and environmental stress on macroalgal biomass in subtropical rocky shores: modulation of bottom-up inputs by wave action. J Exp Mar Biol Ecol 463:39-48

Fong P, Smith TB, Wartian MJ (2006) Epiphytic cyanobacteria maintain shifts to macroalgal dominance on coral reefs following ENSO disturbance. Ecology 87:1162-1168

Fowler-Walker MJ, Wernberg T, Connell SD (2006) Differences in kelp morphology between wave sheltered and exposed localities: Morphologically plastic or fixed traits? Mar Biol 148:755-767

Hastie T, Tibshirani RJ (1990) Generalized additive models. Chapman \& Hall, London

*Hay KB, Poore AGB, Lovelock CE (2011) The effects of nutrient availability on tolerance to herbivory in a brown seaweed. J Ecol 99:1540-1550

Holleman K (2011) Comparison of submarine groundwater discharge, coastal residence times, and rates of primary productivity, Manualua Bay, Oahu and Honokohau Harbor, Big Island, Hawaii, USA. MSc thesis, University of Hawai'i at Mānoa, Honolulu, HI 
Howarth RW, Sharpley A, Walker D (2002) Sources of nutrient pollution to coastal waters in the United States: implications for achieving coastal water quality goals. Estuaries 25:656-676

Huisman JM, Abbott IA, Smith CM (2007) Hawaiian reef plants. University of Hawai'i Sea Grant College Program, Honolulu, HI

Hurd CL (2000) Review: water motion, marine macroalgal physiology, and production. J Phycol 36:453-472

* Israel A, Martinez-Goss M, Friedlander M (1999) Effect of salinity and $\mathrm{pH}$ on growth and agar yield of Gracilaria tenuistipitata in laboratory and outdoor cultivation. J Appl Phycol 11:543-549

Johnson AG, Glenn CR, Burnett WC, Peterson RN, Lucey PG (2008) Aerial infrared imaging reveals large nutrientrich groundwater inputs to the ocean. Geophys Res Lett 35:L15606

Jonsson PR, Granhag L, Moschella PS, Aberg P, Hawkins SJ, Thompson RC (2006) Interactions between wave action and grazing control the distribution of intertidal macroalgae. Ecology 87:1169-1178

Keddy PA (1982) Quantifying within-lake gradients of wave energy: interrelationships of wave energy, substrate particle size and shoreline plants in Axe Lake, Ontario. Aquat Bot 14:41-58

Khan FS, Ansari AA (2005) Eutrophication: an ecological vision. Bot Rev 71:449-482

Kilar JA, McLachlan J (1986) Ecological studies of the alga Acanthophora spicifera (Vahl) Børg. (Ceramiales: Rhodophyta): vegetative fragmentation. J Exp Mar Biol Ecol 104:1-21

Knee $\mathrm{K}$, Street JH, Grossman EE, Boehm AB, Paytan A (2010) Nutrient inputs to the coastal ocean from submarine groundwater discharge in a groundwater-dominated system: relation to land use (Kona coast, Hawaii, USA). Limnol Oceanogr 55:1105-1122

Koch EW (1993) The effect of water flow on photosynthetic processes of the alga Ulva lactuca. Hydrobiologia 260-261: 457-462

Koehl MAR (1986) Seaweeds in moving water: form and mechanical function. In: Givnish TJ (ed) On the economy of plant form and function. Cambridge University Press, Cambridge

Kraufvelin P (2007) Responses to nutrient enrichment, wave action and disturbance in rocky shore communities. Aquat Bot 87:262-274

Kraufvelin P, Lindholm A, Pedersen MF, Kirkerud LA, Bonsdorff E (2010) Biomass, diversity and production of rocky shore macroalgae at two nutrient enrichment and wave action levels. Mar Biol 157:29-47

Lapointe BE (1985) Strategies for pulsed nutrient supply to Gracilaria cultures in the Florida Keys: interactions between concentration and frequency of nutrient pulses. J Exp Mar Biol Ecol 93:211-222

Lapointe BE (1997) Nutrient thresholds for bottom-up control of macroalgal blooms on coral reefs in Jamaica and southeast Florida. Limnol Oceanogr 42:1119-1131

Leon-Soon S (2017) Biophysical interactions: influence of water flow on nutrient distribution and nitrate uptake by marine algae. PhD dissertation, University of Hawai'i at Mānoa, Honolulu, HI

Lilliesköld Sjöö GL, Mörk E, Andersson S, Melander I (2011) Differences in top-down and bottom-up regulation of macroalgal communities between a reef crest and back reef habitat in Zanzibar. Estuar Coast Shelf Sci 91:511-518
Littler MM, Littler DS, Brooks BL (2006) Harmful algae on tropical coral reefs: bottom-up eutrophication and topdown herbivory. Harmful Algae 5:565-585

KLyons DA, Arvanitidis C, Blight AJ, Chatzinikolaou E and others (2014) Macroalgal blooms alter community structure and primary productivity in marine ecosystems. Glob Change Biol 20:2712-2724

*Magalhaes WF, Bailey-Brock JH (2014) Polychaete assemblages associated with the invasive green alga Avrainvillea amadelpha and surrounding bare sediment patches in Hawaii. Mem Mus Vic 71:161-168

Magurran AE (2004) Measuring biological diversity, $2^{\text {nd }}$ edn. Blackwell Science, Oxford

McClanahan T, Polunin N, Done T (2002) Ecological states and the resilience of coral reefs. Conserv Ecol 6:18

McCook LJ (1999) Macroalgae, nutrients and phase shifts on coral reefs: scientific issues and management consequences for the Great Barrier Reef. Coral Reefs 18: 357-367

McCune B, Grace JB (2002) Analysis of ecological communities. MjM Software Design, Gleneden Beach, OR

McGowan MP (2004) Submarine groundwater discharge: freshwater and nutrient input into Hawaii's coastal zone. Master's thesis, Department of Geology and Geophysics, University of Hawai'i at Mānoa, Honolulu, HI

Muthukrishnan R, Fong P (2014) Multiple anthropogenic stressors exert complex, interactive effects on a coral reef community. Coral Reefs 33:911-921

Naim O (1993) Seasonal responses of a fringing reef community to eutrophication (Reunion Island, western Indian Ocean). Mar Ecol Prog Ser 99:137-151

National Data Buoy Center (2017) Station OOUH1 - 1612340 - Honolulu, HI. www.ndbc.noaa.gov/station_history.php? station=oouh1 (accessed 15 May 2017)

NRC (National Research Council) (2000) Clean coastal waters: understanding and reducing the effects of nutrient pollution. National Academies Press, Washington, DC

Nelson CE, Donahue MJ, Dulaiova H, Goldberg SJ and others (2015) Fluorescent dissolved organic matter as a multivariate biogeochemical tracer of submarine groundwater discharge in coral reef ecosystems. Mar Chem 177: 232-243

Nishihara GN, Terada R (2010) Species richness of marine macrophytes is correlated to a wave exposure gradient. Phycol Res 58:280-292

Norderhaug KM, Christie H, Rinde E, Gundersen H, Bekkby $\mathrm{T}$ (2014) Importance of wave and current exposure to fauna communities in Laminaria hyperborean kelp forests. Mar Ecol Prog Ser 502:295-301

Ocean Commission (2004) An ocean blueprint for the $21^{\text {st }}$ century. Final Report. US Commission on Ocean Policy, Washington, DC

*Paytan A, Shellenbarger GG, Street JH, Gonneea ME, Davis K, Young MB, Moore WS (2006) Submarine groundwater discharge: an important source of new inorganic nitrogen to coral reef ecosystems. Limnol Oceanogr 51:343-348

*Pihl L, Svenson A, Moksnes POH, Wennhage H (1999) Distribution of green algal mats throughout shallow soft bottoms of the Swedish Skagerrak archipelago in relation to nutrient sources and wave exposure. J Sea Res 41: 281-294

Reef R, Pandolfi JM, Lovelock CE (2012) The effect of nutrient enrichment on the growth, nucleic acid concentrations, and elemental stoichiometry of coral reef macroalgae. Ecol Evol 2:1985-1995 
Richardson CM, Dulaiova H, Popp BN, Ruttenberg K, Fackrell JK (2017a) Submarine groundwater discharge drives biogeochemistry in two Hawaiian reefs. Limnol Oceanogr 62(Spec Issue):S348-S363

Richardson CM, Dulai H, Whittier RB (2017b) Sources and spatial variability of groundwater-delivered nutrients in Maunalua Bay, Oahu, Hawai'i. J Hydrol: Regional Studies 11:178-193

Ricketts EF, Calvin J, Hedgpeth JW, Phillips DW (1985) Between Pacific tides. Stanford University Press, Palo Alto, CA

Riis T, Hawes I (2003) Effect of wave exposure on vegetation abundance, richness and depth distribution of shallow water plants in a New Zealand lake. Freshw Biol 48:75-87

Simpson EH (1949) Measurement of diversity. Nature 163: 688

Smith JE, Hunter CL, Smith CM (2001) The effects of herbivory and nutrient enrichment on benthic community structure and development on a Hawaiian Reef. Coral Reefs 19:332-342

Smith JE, Hunter CL, Conklin EJ, Most R, Sauvage T, Squair C, Smith CM (2004) Ecology of the invasive red alga Gracilaria salicornia (Rhodophyta) on O'ahu, Hawai'i. Pac Sci 58:325-343

Smith JE, Runcie JW, Smith CM (2005) Characterization of a large-scale ephemeral bloom of the green alga Cladophora sericea on the coral reefs of West Maui, Hawai'i. Mar Ecol Prog Ser 302:77-91

Smith JE, Hunter CL, Smith CM (2010) The effects of topdown and bottom-up factors on benthic coral reef community structure. Oecologia 163:497-507

Smith VH (2003) Eutrophication of freshwater and coastal marine ecosystems a global problem. Environ Sci Pollut Res 10:126-139

Stimson J, Larned S, McDermid K (1996) Seasonal growth of the coral reef macroalga Dictyosphaeria cavernosa Borgesen and the effects of nutrient availability, temperature and herbivory on growth rate. J Exp Mar Biol Ecol 196:53-77

Thomas FIM, Cornelisen CD (2003) Ammonium uptake by seagrass communities: effects of oscillatory versus unidirectional flow. Mar Ecol Prog Ser 247:51-57

Editorial responsibility: Morten Pedersen,

Roskilde, Denmark
Valiela I, McClelland J, Hauxwell J, Behr PJ, Hersh D, Foreman K (1997) Macroalgal blooms in shallow estuaries: controls and ecophysiological and ecosystem consequences. Limnol Oceanogr 42:1105-1118

* Vermeij MJA, Dailer ML, Smith CM (2009) Nutrient enrichment promotes survival and dispersal of drifting fragments in an invasive tropical macroalga. Coral Reefs 28: 429-435

*Walters LJ, Smith CM (1994) Rapid rhizoid production in Halimeda discoidea Decaisne (Chlorophyta, Caulerpales) fragments: a mechanism for survival after separation from adult thalli. J Exp Mar Biol Ecol 175:105-120

*Walters LJ, Smith CM, Coyer JA, Huter CL, Beach KS, Vroom PS (2002) Asexual propagation in the coral reef macroalga Halimeda (Chlorophyta, Bryopsidales): production, dispersal and attachment of small fragments. J Exp Mar Biol Ecol 278:47-65

Wernberg T, Vanderklift MA (2010) Contribution of temporal and spatial components to morphological variations in the kelp Ecklonia (Laminariales). J Phycol 46:153-161

Wiencke C, Bischof K (2012) Seaweed biology: novel insights into ecophysiology, ecology and utilization. SpringerVerlag, Berlin

Williams GJ, Smith JE, Conklin EJ, Gove JM, Sala E, Sandin SA (2013) Benthic communities at two remote Pacific coral reefs: effects of reef habitat, depth, and wave energy gradients on spatial patterns. PeerJ 1:e81

Wood SN (2006) Generalized additive models: an introduction with R. Chapman \& Hall/CRC Press, Boca Raton, FL

*Wood SN (2011) Fast stable restricted maximum likelihood and marginal likelihood estimation of semiparametric generalized linear models. J R Stat Soc Series B Stat Methodol 73:3-36

*Young C, Tamborski J, Bokuniewicz H (2015) Embayment scale assessment of submarine groundwater discharge nutrient loading and associated land use. Estuar Coast Shelf Sci 158:20-30

* Zhang J, Mandal AK (2012) Linkages between submarine groundwater systems and the environment. Curr Opin Environ Sustain 4:219-226

Zuur AF, Ieno EN, Smith GM (2007) Analysing ecological data. Springer Science and Business Media, New York, NY

Submitted: March 13, 2018 ; Accepted: May 12, 2019

Proofs received from author(s): June 26, 2019 